\title{
Pobrezia Energetikoa: \\ Fenomenoaren hurbilketa kontzeptuala, Ekonomia Sozial eta Solidarioarekiko loturak*
}

\author{
Energy poverty: conceptual approach to the phenomenon, \\ connections with the Social and Solidarity-based Economy
}

\author{
Peru Domínguez Olabide
}

Euskal Herriko Unibertsitatea (UPV/EHU) - Ekonomia Sozial eta Solidarioa masterreko ikaslea

DOI: $10.1387 /$ reves.20521

Fecha de entrada: 03/07/2018

Fecha de aceptación: 16/10/2018

\begin{abstract}
Aurkibidea: 1. Sarrera.-2. Zer da pobrezia energetikoa? 2.1. Terminologiaren ur handietan: Fuel Poverty ala Energy Poverty? 2.1.1. Ikuspegi dikotomikoa. 2.1.2. Energia zerbitzuen ikuspuntua. 2.1.3. Ohar osagarri batzuk. 2.2. Pobrezia Energetikoa: Pobrezia orokorretik berezitako arazo zehatz gisa?-3. Pobrezia energetikoaren lekua Ekonomia Sozial eta Solidarioaren baitan. 3.1. Energia pobreziaren ondorioak ikustarazi eta energia, bizitza duhin baterako oinarrizko eskubide gisa aitortzeko urratsak ematen lagundu. 3.2. Gabezia energetikoko egoerak ekiditeko neurri, estrategia eta ekintzak aurrera eraman. 3.1.1. Identifikazioa. 3.1.2. Energia horniketa, sentsibilizazioa eta erlazionaturiko jarduerak. 3.2.3. Interbentzioa.-4. Ondorioak. - 5. Eskerrak.-6. Bibliografia.
\end{abstract}

\section{Laburpena:}

Lan honek, inguru akademiko, mugimendu sozial, eta orokorrean, mendebaldeko gizartearen imaginario kolektiboan gero eta presentzia handiagoa lortu duen pobrezia energetikoaren gaiari hurbilketa bat egitea izan du helburu. Analisi honek, bi atal bereizi aurkezten ditu. Lehenengoan, fenomenoaren hurbilketa kontzeptual bat eginez, pobrezia energetikoaren literaturaren baitan aurkitu litezkeen bi joera teoriko nagusiak aurkezten dira, "ikuspegi dikotomikoa» eta "energia zerbitzuen ikuspegia» hurrenez hurren. Horrekin batera, kontzeptualizazio ariketa aberasteko asmoz, pobrezia energetiko eta pobrezia orokorraren arteko erlazioa aztertu da. Biak era bateratuan edo era bereizian aztertzearen egokitasuna, erabiltzen den pobrezia definizioaren araberakoa dela ondorioztatuz. Bigarren atalean, bestalde,

* Artikulu hau Master Amaierako Lanetik eratorria da, 2018an Gizarte Ekonomia eta Solidarioa Unibertsitate Masterrean aurkezturikoa 
pobrezia energetikoaren eta Ekonomia Sozial eta Solidarioaren artean egon daitezkeen lotura edota bidegurutze posibleak aztertu dira. Bi elkargune nagusi identifikatu dira ahalegin honetan. Lehena, Ekonomia Sozial eta Solidarioko erakundeek energia pobreziaren ondorioak ikustarazteko izango luketen gaitasuna liteke. Bigarrena, erakunde beretsuek gabezia energetikoko egoerak ekiditeko neurri, estrategia eta ekintzak aurrera eramateko gaitasuna liteke. Azken honen baitan, hiru fronte nagusitan paper garrantzitsua lukete erakunde hauek, hala nola, identifikazioan, energia horniketan eta interbentzioan.

\title{
Hitz gakoak:
}

Pobrezia energetikoa; Pobrezia; kontzeptualizazioa; Ekonomia Sozial eta Solidarioa / Energy poverty; Poverty; Conceptualization; Social and Solidarity Economy.

\begin{abstract}
:
The following paper intends to make an approach to energy poverty. In recent years, this issue has gradually drawn the attention of the academic world and social movements alike, becoming an urgent problem to solve in western societies. The analysis is split in two parts. On the first part, carrying out a conceptual approach of the issue at hand, the two main theoretical streams present in the literature of energy poverty are introduced, namely, "the dichotomic perspective" and "the energy services perspective». Furthermore, enriching this conceptualization exercise, the relation between energy poverty and poverty in general has been assessed, coming to the conclusion that the pertinence of whether to carry out a joint or a separate analysis boils down to the definition of poverty. On the second part, the associations and relationships that could exist between energy poverty and the Social and Solidarity Economy have been examined, coming up with two potential bonds between them. Firstly, the capability of the organizations of the Social and Solidarity Economy to raise awareness about the consequences of energy poverty. Secondly, their capability to implement measures, strategies and actions to mitigate energy poverty. In this later field of action, these organizations could have a distinguished role concerning identification, energy supply and intervention.
\end{abstract}

\section{Claves Econlit:}

General Welfare: Basic Needs 131; Measurement and Analysis of Poverty: Poverty Analysis 132; Nonprofit Institutions: Not for profit L31.

\section{Sarrera}

XxI. mendean aurrera egin ahala, herrialde industrializatuetako aberastasuna, nonbait, gero eta gehiago materia gris, jakintza, informazio, ikerketa 
eta eraberritzeko gaitasunean oinarritzen ari den honetan, desmaterializatutako ekonomiaren oinarria —ekonomia materialarena bezalatsu, bestaldezein den gogora ekartzea komeni da: energia (Bueno Mendieta, 2007). Gaur egungo gizarteko ongizatearen zutarrietako bat, energiaren erabilera intentsiboak eskaintzen duen oparotasuna dela aitortu liteke, gure bizitzen egunerokotasunean garbi islatzen delarik. Esan liteke, funtzionatu ahal izateko energia iturriren bat behar duten gailuek gero eta presentzia handiagoa dutela jendartearen bizitzetan. Transformazio horren nolabaiteko lekukotasuna izateko, Nazioarteko Energia Agentziak —ingeleseko IEA laburduraz ere aski ezaguna- emandako datuetara jo daiteke. 1971 eta $2014^{1}$ urteak alderatuz gero, Ekonomia Lankidetza eta Garapenerako Erakundearen -ELGE aurrerantzean - baitako herrialdeetan, batezbesteko per capita energia kontsumoa $^{2}$ 3.956,62 Kwh-tik 7.994,74 Kwh izatera pasa da. Beste era batera esanda, 40 urte inguruko denbora tarte batean, energia kontsumoa \% 102, 06an hazi da, edo gauza bera dena, bikoiztu egin da. Bien bitartean, ELGE-ko populazioa $\% 39,95$ ean hazi denez ${ }^{3}$, eta aldi berean, gailuen efizientzia energetikoak gora egin duela aurreiritzi daitekeenez, ondoriozta liteke gizarteak energiarekiko duen dependentziak gora egin duela azken hamarkadetan.

\title{
1.1 Grafikoa
}

Guztizko energia kontsumoa ELGE-ko herrialdeetan, erabileraren arabera

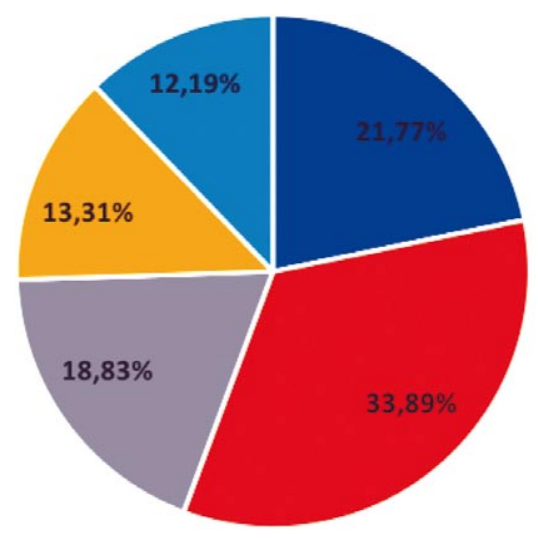

\author{
- Industria \\ - Garraioa \\ " Etxebizitzak \\ " Merkataritza eta zerbitzu publikoak \\ - Besteak
}

Iturria: Ekoizpen propioa IEA Headline Global Energy Data (2017)-ko datuetatik abiatuta.

1 Erabilgarri dauden azken urteko datuak.

2 Zentral elektriko eta kogenerazio instalazioetako energía ekoizpena, igorpen, banaketa eta transformazioan galdutakoa kenduz eta guztizko biztanleariagatik zatituz lortzen den estatistika litzake.

3 898.252.000 pertsonatik 1.257.114 pertsonara hazi da ELGE-ko populazioa aipatutako urte horietan. Iturria ELGE: www.oecd.org 
Industria, garraio eta azken batean sistema sozioekonomikoko alderdi guztiek energia kontsumo maila esanguratsuak beharko lituzkete lanean jarraitzeko. Beste behin, IEA erakundearen datuetara jotzen badugu, ELGEko herrialdeen osotasunerako, deigarria egiten da guztizko energia kontsumoaren \% 18,83a etxebizitzetan egiten dela ${ }^{4}$. 1.1 Grafikoari so eginez, beste erabilerekin alderatuta, etxebizitzako kontsumoa esanguratsua dela ikus daiteke, herrialde industrializatuetako pertsonen bizitzetan energiak duen ezinbestekotasuna agerian jarriko lukeelarik.

Nazio Batuen Giza Eskubideen Adierazpeneko 25. atalean adierazten denez, "Pertsona orok du bizimodu egokia izateko eskubidea, bai berari eta bai bere familiari osasuna eta ongizatea bermatuko diena, eta batez ere janaria, jantziak, bizitokia, mediku sorospena eta gizarte-zerbitzuak; eta baita lanik eza, gaixotasuna, elbarritasuna, alarguntasuna, zahartzaroa edo bizibidea nahi gabe galtzeko beste kasuren bat gertatzen denerako asegurua izateko eskubidea ere» (UN General Assembly, 1948). Ondorioz, energia esplizituki aipatzen ez denez, orokorrean, oinarrizko eskubide gisa aintzatetsia ez dela izan esan liteke, nahiz eta aipatzen den «bizimodu egoki» horretarako ezinbestekoa suertatu. Horrela, oro har, estatuaren interbentzio handiko sektorea izan den arren energiarena, iritzi liteke sektore beraren ezaugarrien eta daukan interes estrategikoaren ondorio izan dela. Aitzitik, osasun eta hezkuntza sistema publikoen kasuetan, interbentzioa, horiek oinarrizko eskubide gisa aitortzean egon liteke. Beraz, energiaren erabilera izugarri handitu den honetan, bere errekonozimenduan inongo urrats esanguratsurik ez dela eman iritzi daiteke.

Testuinguru honetan, 2008ko krisialdi ekonomikoaren etorrerarekin, ordura arte herrialde industrializatuetan arreta gutxi bereganatutako fenomeno batek, gero eta oihartzun handiagoa hartzen zuela zirudien; pobrezia energetikoak alegia. Inguru akademikoaren arreta bereganatzeaz haratago, mugimendu sozial ezberdinen aldarrikapenetan gero eta presentzia handiagoa izatea lortu zuen gai honek (Albaladejo eta Berenguer, 2016).

Horiek horrela, lan honen helburua, berriki ikusgarritasuna lortu duen pobrezia energetikoaren gaiari hurbilketa bat egitea da. Hurbilketa honetan, analisia baldintzatzen duten oinarrizko bi ezaugarri egongo lirateke. Batetik, pobrezia energetikoaren hurbilketarako markoa Herrialde Industrializatu bateko testuinguruan kokatu da. Honen atzean legokeen arrazoi behinena, aurkeztuko den lanari izaera berritzailea ematearena liteke. Izan ere, Garapen Bideko Herrialdeetan, pobrezia energetikoaren azterketa akademikoak tradizio luzea du, asko idatzi eta ikuspuntu teoriko sendoak eraiki direlarik haren inguruan. Aldiz, ikusi berri denez, Herrialde Indus-

\footnotetext{
42015 urteko datuak.
} 
trializatuetan fenomenoaren azterketak 2008ko krisiaz geroztik jasotzen du bultzada. Bestetik, lan hau garatzeko erabilitako iturriak, literatura akademiko eta grisean oinarritu dira soilik. Ezaugarri edo kriterio honen helburua, panfleto edota iritzi hutsean oinarritutako lanek eragin dezaketen distortsioa ekiditea izan da.

Jatorrizko lana hiru atal nagusitan egituratua badago ere, aldizkariaren ezaugarriak kontutan harturik lehenengo bi atalen aurkezpena egingo da. Lehenak, zer da pobrezia energetikoa galderari erantzun bat ematea du helburu. Erantzun horren bilaketan, lehenik eta behin pobrezia energetikoaren literaturaren baitan aurkitu litezkeen bi joera teoriko nagusiak aurkezten dira. Aipatu, horien identifikazioa eta bakoitzaren ezaugarri nagusien zehaztapena, egileak egindako berrikuspen lanetik sorturikoa dela. Atal berdinaren barruan, pobrezia energetikoa pobrezia orokorretik bereiztearen auzian barneratuko da lana, bereizketaren aldeko eta kontrako jarreren argumentazio lerroak aztertuz. Bigarren atalean, lan hau txertatzen den nolabaiteko jakintza lerroari edo ibilbideari men eginez, pobrezia energetikoaren eta ESSren artean egon daitezkeen lotura edota bidegurutze posibleak aztertzen dira. Honen inguruan asko ez denez idatzi, analisiak izaera esploratzailea izango du, lotura posibleak proposatuko direlarik. Amaiera gisa, egilearen gogoetatan oinarrituta, hainbat ondorio aurkeztuko dira.

\section{Zer da pobrezia energetikoa?}

Biztanleriaren zati esanguratsu bat pobrezia mota berezi bat pairatzen ari denaren kontzientzia, ez zegoen inondik ere hedatuta duela urte gutxira arte Europar Batasuneko - EB aurrerantzean - esparru politiko eta akademikoetan. Erresuma Batua eta Irlanda ziren, agian, salbuespen bakarrak, horietan, 90eko hamarkadaz geroztik, pobrezia energetikoa - Fuel poverty etiketarekin - eztabaida, politika publiko eta ikerketen objektu bilakatu baitzen jada. Ondorioz, bi herrialde horien arazo endemiko gisa hartu zen pobrezia energetikoa urte luzeetan zehar, nonbait, EBko gainerako herrialdeetan inolako arretarik eman ez zitzaiolarik politika eta ikerkuntzaren alorrean.

Haatik, Dubois eta Meier (2016) egileek adierazi bezala, azken urteotan gertatutako hainbat aldaketek, hots, energia hornikuntza baldintzen eta egoera ekonomiko orokorraren aldaketek, energia ordaintzeko ahalmenaren eta oinarrizko behar energetikoak asetzeko gabezien inguruan galdera ugari azalerarazi dituzte. Aipatutako egileek, EBko herrialde desberdinentzat amankomunak diren aldaketa-patroiak azpimarratzen dituzte beren analisian. Energia hornikuntzari dagokionean, bi inflexio puntu identifikatu dituzte. Bata, 1996ko elektrizitate eta gas merkatuen libera- 
lizazioa, herrialde gehienetan prezioen erregularizazioa deuseztatzea ekarri zuena ${ }^{5}$. Bestea, 2007 urteaz geroztik orokortu diren klima eta energia politikak lirateke. Egile horien esanetan, bi faktore horien elkarrekintza giltzarria da energia kostuen goranzko jarrera azaltzeko. Modu laburrean esanda, energia iturri berriztagarrien garapena eta ezarpena eta merkatuko prezio aldaketen kostuak kontsumitzaileek hartu dituzte beren gain, ondorioz faktura energetiko altuagoei aurre egin behar dietelarik. Bestalde, egoera ekonomiko orokorrari dagokionean, 2008ko ekonomia krisi bortitzak, faktura energetikoa ordaintzeko familien ahalmena murriztu du Batasuneko herrialde gehienetan (Dubois eta Meier, 2016). Era berean, azken hamarraldian zenbait EBko herrialdeetan bizitutako ekonomia krisia bortitzaren ondotik, Albaladeio eta Berenguer (2016) egileek adierazi gisa, atsekabe politiko eta ekonomikoko testuinguruan aktore sozio-politiko berriek eta 'gizarte zibileko' mugimenduek protagonismoa bereganatu zuten, honek ere nolabaiteko eragina izango zuelarik, seguruenik, aipatu fenomenoan.

Testuinguruaren aldaera honek, pobrezia energetikoaren afera eztabaida publiko, politiko eta mediatikoaren lehen lerrora ekartzea eragin du. Era honetan, gaia aintzatespen graduala lortzen ari da azken urteotan EBko hainbat herrialdetan eta gainera, aipamena izatea lortu du EBko hainbat instituzioren dokumentu ofizialetan (Maxim et al., 2016). Are gehiago, bai erakunde ofizialek eta baita gobernuz kanpokoek, EBrentzako definizio bat ezartzeko saiakera eskatzen ari dira (Tirado Herrero, 2017). Norabide horretan, esanguratsua da Schumacher et al. (2015) egileek europar parlamentuko Industria, Ikerketa eta Energia Batzordearen izenean osatutako txostena, non ahalegin horretarako lehen zutarriak ezartzen diren.

Beraz, ikusi berri dugunez, pobrezia energetikoaren inguruko kezka britainiar uharteetatik EB osora hedatu da, ekialdeko eta hegoaldeko herrialdeetan oihartzun handiena eduki duelarik. Izan ere, gaur egun arte fenomenoa EB osoan neurtzeko saiakera egin duten ikerketa lanek —batzuk aipatzearren Healy eta Clinch (2002), Thomson eta Snell (2013) eta Maxim et al. (2016) - , mediterraneo inguruan eta herrialde komunista ohietan topatu baitituzte pobrezia energetiko maila altuenak. Horiek horrela, atal honetako datozen lerroetan pobrezia energetikoaren kontzeptualizazioan arituko gara, horretarako, literatura akademikoan kontzeptuak izan duen bilakaera gertutik aztertuz eta bere inguruan sortu diren ikuspuntu nagusien inguruko zertzeladak emanez.

\footnotetext{
5 Energia merkatuen liberalizazioaren eta pobrezia energetikoaren arteko erlazioetan sakontzeko ikusi Chester eta Morris (2011) eta Chester (2014).
} 


\subsection{Terminologiaren ur handietan: Fuel Poverty ala Energy Poverty?}

Pobrezia energetikoari erreferentzia egiteko garaian termino ezberdinak erabili ohi dira inguru akademikoan, besteak beste, Fuel poverty, Energy poverty, Energy precariousness eta Energy vulnerability (Bouzarovski eta Petrova, 2015). Hala eta guztiz ere, literaturaren parte esanguratsu batek —ikus, adibidez, Atsalis et al. (2016), Gouveia et al. (2018), Belaïd (2018), Roberts et al. (2015), Papada eta Kaliampakos (2017), eta Aristondo eta Onaindia (2018) - Fuel Poverty eta Energy Poverty adierazpenak darabiltza soilik, beraz, esan liteke bi horiek direla pobrezia energetikoari erreferentzia egiterako garaian gehien erabiltzen diren terminoak. Bataren zein bestearen erabilerari dagokionean ez dirudi literaturan adostasuna dagoenik. Dena dela, orokortze eta sinplifikatze ariketa batean — galdu daitezkeen ńabardura garrantzitsutaz kontziente - bi joera nagusi identifka daitezke terminologiaren erabileraren baitan, eta horien analisiari ekingo diogu jarraian.

\subsubsection{IKUSPEGI DIKOTOMIKOA}

Alde batetik, Bouzarovski eta Petrovak (2015) agerian jarri bezala, literaturan nahiko orokortua dagoen jarrera bat, inguru geografikoaren araberako terminoen erabilera da; alegia, fuel poverty etiketa Herrialde Garatuetarako ${ }^{6}$ eta energy poverty Garapen Bideko Herrialdeetarako erabiltzea. Aitzitik, terminoek fenomeno berari erreferentzia egitetik urrun, tankera oso ezberdineko arazo sozioekonomikoak adieraziko lituzkete. Fuel poverty adieraren bitartez, energia ordaintzeko gaitasun ezari erreferentzia egiten zaion bitartean, energy povertyk zerbitzu energetiko modernoetarako sarbide edo irisgarritasun eza islatuko luke (Maxim et al. 2016). Beraz, Bouzarovski eta Petrova (2015) egileei jarraituz, pobrezia energetikoaren baitako joera honek fenomenoaren ikuspegi dikotomikoa daukala esan daiteke.

${ }^{6}$ Garapenaren eztabaidaren baitan, Garapena kontzeptua bera, ailegatu beharreko estadio bat denaren ikuspuntua gainditu bada ere, herrialde garatu eta azpigaratu nomenklatura honek garapenaren ikuspuntu hauxe izango lukeela bere oinarrian iradokitzen digu. Hortaz, nazioarteko erakunde multilateral garrantzitsuenak, Nazio Batuen Erakundeak (NBE) bestea beste, Giza Gaitasunen ikuspuntua bere egin badute ere, Pobrezia Energetikoaren baitako literaturak ez ditu kontuan hartzen ńabardura horiek. Ondorioz, lan honen baitan "Garatutako» eta "Garapen bideko herrialde» adierak erabiltzen dira, ez garapenaren baitako marko teoriko bat bestearen gainetik jartzeko, literaturak darabiltzan terminoak islatzeko baizik. Are gehiago, ziurrenik, imaginario sozialean duen errotzea kontuan hartuz, kontzeptu horien erabilerak azaldutakoa hobeto ulertzea lortuko luke. 
Adierazi bezala, joera honen baitan, terminologia ezberdinak errealitate ezberdina du hizpide, eta ondorioz, bakoitzaren gerizpean aurrera eraman diren ikerketen norabidea baldintzatu dutenaren zantzuak leudeke. Fuel poverty terminoarekin hasiz, esan liteke Britainiar uharteetan kontzeptuak izandako garapenari estuki lotuta egon dela bere bilakaera. Aintzindaritzat jo daitekeen Boardman egilearen lanak proposatuari jarraituz, 2000. urtean, Warm Homes and Energy Conservation act legearen bitartez fuel poverty terminoaren ondoko definizioa ezarri zen Britainia Handian: «Pertsona bat pobrezia energetiko - Fuel poverty - egoeran dagoela esango da baldin eta arrazoizko kostuan etxea bero mantentzea ezinezkoa zaion errenta baxuko familia batean bizi bada» (Miniaci et al. 2014, 290. Or.). Aldi berean, arrazoizko kostu hori zehazteko ahaleginean lege berak errentaren gaineko \% 10 atalasea ezarri zuen, hots, etxeko berotasuna mantentzeko errentaren \% 10a baino gehiago erabili behar zuten familietako kideak pobre energetiko kotsideratzen zituen (Day et al. 2016). Azken egile horien esanetan, Britainia Handian ezarritako marko honek berebiziko eragina izan zuen gainontzeko herrialde garatuetan, bai pobrezia energetikoaren inguruko politikak eta baita ikerketak abian jartzeko garaian. Ikusi dugunez, beraz, fuel poverty terminoak etxean erosotasun termikoa (Day et al. 2016) erdiesteko familiek duten ezintasunari egingo lioke erreferentzia. Ezintasuna aipatzean, etxea era egokian berotu ahal izateko errentaren baitako gehiegizko ahalegina -\% 10eko atalasea - litzake mintzagai. Modu honetan definitzen dute pobrezia energetikoa besteak beste ondoko egileek; O’Meara (2016), Roberts et al. (2015), Legendre eta Ricci (2015) eta Sánchez et al. (2017). Aitzitik, Thomson eta Snell (2013) egileen hitzetan, terminoaren erabileran trinkotasun eza nabaria litzateke, batez ere Europar Batasunean, egile askok eta askok fenomeno berari erreferentzia egiteko - etxean erosotasun termikoa erdiesteko ezintasuna- energy poverty etiketa erabiliko luketelarik. Hala eta guztiz ere, adiera bat edo beste erabili, pobrezia energetikoaren definizio legal bat ezarri duten Europar Batasuneko estatu bakarrenetarikoek, Erresuma Batua, Irlanda eta Frantzia (Schumacher et al., 2015), ikuspegi honetan oinarritu direlaren zantzuak leudeke.

Fuel poverty terminoaren analisia itxiz, literaturako lehen joera honen baitan energy poverty etiketak isladatuko lukeena aztertzeari ekingo diogu. Sarreran aipatu den ildotik, lan honetan, pobrezia energetikoak herrialde industrializatuetan dituen ezaugarrietan sakondu nahi denez, beste errealitateetako gorabeherak azaletik aztertuko dira. Gauzak horrela, arestian azaldutakoa gogora ekarriz, Garapen Bideko Herrialdeetan zerbitzu energetiko modernoetarako sarbide edo irisgarritasun eza adierazteko erabiliko litzateke energy poverty terminoa. Petrova et al. (2013) egileek adierazitakoaren bidetik, sarbide eza horrek, azpiegitura gabezia eta garapen ekonomikoa maila apala lituzkete beren erroan. Horrenbestez, gaiari tratamendua eman 
dioten lan akademiko eta zientifikoak, Bouzarovski eta Petrova (2015) egileek adierazi gisa, garapenari buruzko Ikasketen disziplinatik egin dira, batik bat, «energia sistema sozio-teknikoen baitan sarbide, ekitate eta inbertsio arazoetan fokua jarriz» (Bouzarovski eta Petrova, 2015, 33. or.).

Era laburrean esanda, Pobrezia energetikoaren joera honek fenomenoaren irakurketa dikotomiko bat egiten du - Ikuspegi dikotomiko etiketa erabiliz egingo diogu erreferentzia joera honi aurrerantzean-, Garapen Bideko eta Herrialde garatu arteko zatiketa garbia eginez, bakoitzarentzat termino espezifiko bat aurreukusiz, Energy Poverty eta Fuel Poverty, hurrenez hurren. Lehenak sarbide eta irisgarritasun eza hizpide dituen bitartean, bigarrenak erosotasun termikoa erdiesteko ezintasuna islatuko luke. Ikuspuntu honen baitan, badira haratago joan diren eta mugak are gehiago zehazten saiatu diren egileak. Esanguratsuenak, baliteke, Li et al. (2014) izatea, hauek fuel poverty/energy poverty binomioa, klima hotzeko herrialde aberatsetara batetik, eta edozein klimatako herrialde pobreetara bestetik, mugatzea proposatzen zuten hurrenez hurren. Kontzeptuaren mugapen eta zehaztapen saiakerak alde batera utzita, pobrezia energetikoa ulertzeko ikuspuntu honi zuzendutako kritika nagusia, testuinguru aniztasunari egokitzeko gaitasun eza litzateke (Bouzarovski eta Petrova, 2015). Horien hitzetan, munduan zehar energiaren baitako egoera eta praktiken aniztasunak sostengaezina bilakatzen dute joera honek egiten duen irakurketa. Day et al. (2016) egileek adierazi bezala, Herrialde Garatuetan pobrezia energetikoaren arazoa ulertzerako garaian, inguru termiko desegoki batek sor ditzaken osasun arazo eta heriotzek dominatu dute diskurtsoa. Horrela, energia gabeziak sor ditzazken beste ondorio batzuk aztertu gabe utziz. Hartara, egile berdinek, ikuspegi dikotomikoak pobrezia orokorraren ulermen zabalagorekiko dituen lotura kontzeptual ahulak azpimarratu dituzte. Kritika hauetan abiapuntua hartuta, jarraian aurkeztuko dugun pobrezia energetikoaren baitako bigarren joerak, ikuspegi dikotomiko hori apurtuko luke, fenomenoaren azterketan Garapen Bideko Herrialdeetan erabilitako kontzeptuak, Herrialde Garatuen azterketan erabiliz (Bouzarovski eta Petrova, 2015). Horrela, eremu geografiko guztietara egokituko litzatekeen ikuspuntua izango litzatekelarik.

\subsubsection{ENERGIA ZERBITZUEN IKUSPUNTUA}

Pobrezia energetikoaren baitako bigarren joera honen ezaugarriak aztertzera sartu aurretik, ohar pare bat ematea aproposa liteke testuinguruan hobeto kokatu ahal izateko. Hain zuzen, pobrezia energetikoa eragiten duten faktoreen —zaurgarritasun-faktoreak Bouzarovski eta Petrova (2015) egileen hitzetan - inguruan idatzi dena mahai gainean jartzea komenigarria dela aintzatesten da. 
Analisiaren fokua Herrialde Garatuetan ipiniz, ikusmolde dikotomikoaren baitako egileen artean nolabaiteko adostasuna antzematen dela zaurgarritasun-faktoreak zehazterako garaian esan liteke. Zehazki, hein handi batean hiru faktoreren elkarrekintzatik eratortzen dela pobrezia energetikoa defendatzen dute: Energiaren kostua, Familien errenta maila eta etxearen eta etxetresnen efizientzia energetikoa (O'Meara, 2016; Thomson et al., 2017; Papada eta Kaliampakos, 2016; Maxim et al., 2016; Robinson et al., 2017). Pobrezia energetikoaren baitako bigarren joera honek aipatu berri ditugun zaurgarritasun-faktoreak bere egiten dituen arren, beste batzuk ere aintzat hartzen ditu. Horien zehaztapenean, agian, literaturan oinarri sendoak jarri ez direla argudiatu litekeen arren, bere egiten dituen faktore motek espektro zabala estaltzen dute, hala nola, sarbide, azpiegitura, behar, malgutasun eta praktikekin lotuta dauden faktoreak aintzat hartzen dituzte (Bouzarovski eta Petrova, 2015). Beraz, ordaintzeko ahalmena eta efizientzia energetikoarekin loturiko faktoreak baztertzen ez badituzte ere —ikuspuntu dikotomikotik defendatzen direnak-, errealitatearen dimentsio zabalago bat islatzen duten faktoreak kontuan hartzen dituztela esan liteke.

Aipatu berri dugunetik, ondokoa ikus liteke: Ikuspegi dikotomikoaren baitan pobrezia energetikoa dimentsio bakarrekotzat jo liteken bitartean - erosotasun termikoa lorteko gaitasun eza bezala ulertuta, ordaintzeko ahalmena eta efizientzia energetikoa aintzatetsiz soilik zaurgarritasun-faktore gisa-, bigarren ikuspegi honek fenomenoaren ulermen multidimentsionala izango luke bere baitan (Day et al., 2016), beregan eragiten duten faktore sorta identifikatuz. Horiek horrela, ikuspegi honen baitan definizio bat gailendu dela esan liteke, pobrezia energetikoa sozialki eta materialki beharrezkoa den energia zerbitzu maila erdiesteko familia baten ezintasuna gisa ulertzen duena (Belaïd, 2018, Boemi et al., 2017, Bouzarovski, 2014, Bouzarovski et al., 2016, Maxim et al., 2017, Okushima, 2016, Okushima, 2017, Robinson et al. 2017, Scarpellini et al., 2015 Thomson et al., 2017). Bestearekin alderatuta, ikuspegi honen giltzarria energia zerbitzutan legoke, eta horrexegatik, aurrerantzean, energia zerbitzuen ikuspegi adiera erabiliko dugu.

Munduko bankuaren esanetan, energia zerbitzuak, energia eramaileak ${ }^{7}$ pertsonengan eragindako onurak lirateke (Modi et al., 2005). Definizio honen azpian, Haas et al. (2008) egileek ahotan hartutako arrazoiketa bidea legoke, hau da, pertsonek ez dutela bere horretan energia eskatzen, garbiketa, argiztapena, mugikortasuna, beroketa eta antzerako energia zerbitzuak baizik. Hortaz, beroketaz haratago, gainontzeko energia zerbitzuetan

7 Ingelesezko energy carrier adieraren itzulpena. 
aurkitzen diren gabeziak kontuan hartuko lituzke ikuspegi honek. Lerro honetan kokatzen den literaturaren zai handi batek, energia zerbitzu maila egokia erdiesteko ezintasunaren azterketa plano ekonomikotik egingo luke soilik. Hau da, Maxim et al. (2017) egileek adierazten duten moduan, energia zerbitzuetan familiako errentaren zati handiegia erabili behar izateak definituko luke pobrezia energetiko egoera. Korronte honi kontrapuntua jarriz, hainbat egilek plano ekonomikotik haratago joko lukete ezintasuna aztertzerako garaian ${ }^{8}$, adibide gisa, Buzar (2007) egileak dimentsio geografiko-espazialaren garrantzia azpimarratzen du pobrezia energetikoaren eragile gisa. Desadostasunak desadostasun, energia zerbitzuetan oinarritutako irakurketaren izaera multidimentsionala dela medio, testuinguru ezberdinetan aplikatzeko baliogarritasuna handia liteke Day et al. (2016) egileen esanetan. Are gehiago, egile berdinen esanetan, Garatutako eta Garapen Bideko Herrialdeen arteko arrakala kontzeptualarekin amaituko luke ikusmolde honek, energia eta ongizatearen arteko erlazioak testuinguru ezberdinetan azaleratzeko balioko bailuke. Baliteke beraz, ikuspuntu honen baitan pobrezia energetikoa kontzeptualizatzeko marko unibertsal bat eraikitzea izatea helburu.

Terminologiari so eginez gero, esan liteke, energia zerbitzuen ikuspegiaren baitan fuel poverty eta energy poverty adierak aipatutako errealitateari erreferentzia egiteko sinonimo gisa erabiltzen direla (Bouzarovski, 2014, Boemi et al., 2017, Lenz eta Grgurev, 2017, Belaïd, 2018), baita EBko dokumentu ofizialetan ere (Thomson et al., 2017). Dena dela, hainbat egilek adierazi dutenez (Belaïd, 2018, Boemi et al., 2017) eremu geografikoak eragina du fenomenoa modu batera edo bestera izendatzerako garaian. Horien esanetan, fuel poverty adiera Britainia Handia, Irlanda, Australia, Zeelanda Berria eta AEBtan erabiliko litzake batik bat, EBko gainontzeko estatu kideetan eta Garapen Bideko Herrialdetan energy poverty terminoa hedatuagoa egongo litzatekelarik. Frantziaren kasuan, prekarietate energetiko edo frantsesezko baliokidea den Précarité Energetique erabiliko litzateke (Bouzarovski eta Petrova, 2015).

Azkenik, modu laburrean esanda, Day et al. (2016) egileek azpimarratzen dutenez, energia zerbitzuen ikuspegiak Giza Gaitasunen Ikuspuntik eta pobrezia erlatibotik eratorritako elementuak barneratzea ahalbidetzen du. Izan ere, aurrez definitu denez, sozialki eta materialki beharrezkoak diren energia zerbitzuak erdiesteko ezintasunak, gizarte bateko kide egiten duten bizimodu, ohitura eta ekintzatan parte hartzeko ezintasuna adieraziko luke. Hain zuzen, ikuspegi honen aintzindari den Nussbaum (2001)

${ }^{8}$ Ez dugu ahaztu behar Herrialde Garatuak ardatz gisa hartuz ari garela analisia. Garapen Bideko Herrialdeetan, izan ere, beharrezko energia zerbitzuak erdiesteko ezintasuna plano ekonomikotik haratago aztertu duten lanak ugariak baitira. 
egileak adierazitakoaren ildotik, energia, oinarrizko gaitasunak eskuratzeko aurrebaldintza materiala da, beraz, Giza Gaitasunen Ikuspegiarekin lotura garbia ikusi daitekeela esan liteke. Aurrekotik ere, ikusmolde honen izaera erlatiboa agerian dela argudiatu liteke.

\subsubsection{Ohar osagarri batzuk}

Egin berri dugun analisian oinarrituz, pobrezia energetikoari dagokionean bi joera nagusi leudekela baieztatzea posible den arren, literaturaren parte esanguratsu batek bi ikuspegietako elementuak uztartzen dituztela esatea, ez litzateke seguruenik okerra. Joera hau, bederen, orain arte aipatu ditugun egile askoren lanetan topa daiteke, esaterako, Thomson et al. (2017) eta Papada eta Kaliampakos (2016) egileen lanetan. Honek guztiak, pobrezia energetikoaren kontzeptualizazioari dagokionean heterogeneotasuna, gehiegizko barreiaketa eta adostasun eza eragin duela iritzi liteke. Ondorioz, aurreko atalean azaldu den joera kontzeptual nagusien sailkapena, pobrezia energetikoaren alorreko literaturaren errebisio zabal batetik eratorria da. Hala eta guztiz ere, baliteke, gisa honetako sailkapen proposamenak egotea beste irizpide batzuetan oinarrituta. Nahiz eta, egungo data arte horrelako saiakerarik ez den proposatu, berrikusi eta proposatu diren lanak kontuan izanik, behintzat.

\subsection{Pobrezia Energetikoa: Pobrezia orokorretik berezitako arazo zehatz gisa?}

Pobrezia energetikoaz hitz egiterako garaian, lehenengo sortzen den ezbaietako bat oinarri-oinarrizkoa da: pobrezia orokorretik berezitako arazo zehatz bat den ala ez, hain zuzen. Izan ere, Hills (2011) egileak nabarmendu bezala, badira beste hainbat aspektu, energiaren pareko garrantzia dutenak horietako askok, errenta baxuko familiek ezintasunak dituztela asetzeko. Erresuma Batuko energia idazkari izan zen Peter Walker modu adierazgarrian mintzatu zen aurreko arazoataz, «arropa pobreziaz edota janari pobreziaz hitz egiten ez den bezala, zentzugabekeria da energia pobreziataz hitz egitea» (Bouzarovski, 2014, 277 Orr.) esanez. Horrela, urteetan berezitako arazo gisa kontsideratu ez zen arren, pixkanaka, ikertzaile eta politikarien artean pobrezia energetikoa era berezian tratatzeko zantzuak identifikatzen hasi ziren (Hills, 2011), faktore ezberdinen arteko elkarrekintza konplexuak bere baitan hartzen zituela iritziz (Phimister et al., 2015).

Hills (2012) egilearen hitzetan, pobrezia energetikoaren jatorri, ondorio eta soluzioak arazo ezberdin bat bilakatzen dute. Bere esanetan, hiru kezka nagusiren bidegurutzean aurkituko litzateke: pobrezia, osasuna eta berotegi efektuko gasen murrizketa. Horrexegatik, era berezian tratatuz 
gero, agenda ezberdinetarako win-win-win egoerak sortzeko potentziala izango lukeela argudiatzen du. Aipatutako kezken eta pobrezia energetikoaren artean, jarraian aurkezten diren loturak proposatuko lituzke hizpide dugun egileak. Alde batetik, pobreziari dagokionean, ondorengo arrazoiketa lerroa darabil loturak ezartzeko. Dirua, familien bizi maila zehazteko neurri inperfektua bada ere, kasu askotan diru kopuru bera antzeko erosketa saskiaren baliokide izaten da. Hala eta guztiz ere, energiaren kasuan, egoera guztiz bestelakoa izan ohi da, antzeko beharrak — berokuntza, ur beroa, argiztapena, etab. - dituzten familia berdintsuek, energia behar oso ezberdinak izan ditzaketelarik, eta ondorioz, kostuen artean ezberdintasun handia egon daitekeelarik. Bestetik, osasunari dagokionean, Hills-en (2012) baitan neguan gertatzen diren hilketa gehigarriekin ${ }^{9}$ eta beste hainbat osasun arazorekin lotura zuzena izango luke. Azkenik, berotegi efektuko gasen murrizketari dagokionean, bi lotune identifikatzen ditu egileak. Bata, karbono emisioen aurkako politiken ondorio distributiboen inguruko kezka litzateke. Izan ere, energia berriztagarrirako trantsizioak pobrezia energetikoaren fenomenoa hedarazi baitezake. Bestea, emisio murrizketa helburuak erdiesteko efizientzia energetikoko hobekuntza neurrien onuradunen ingurukoa litzateke. Oro har, errenta baxueneko familiek beharrezko inbertsioak euren kabuz egin ezin dituztenez, nolabaiteko laguntzak aurreikusi beharko lirateke.

Hills (2012) egilearen argudiaketa kontuan hartuz, pobrezia energetikoa era berezian tratatzea beharrezkoa litzateke, neurri zehatzak hartuz, modu horretan aipatutako hiru alderdietan, hots, pobrezia, osasuna eta negutegi efektuko gasen murrizketan, hobekuntzak lortu ahal izateko. Hortaz, Middlemiss (2017) egileak adierazi gisa, pobrezia eta pobrezia energetikoaren problematizazio berezia, ustezko konponbide ezberdin jakin batean errotzen da. Pobrezia energetikoaren kasuan, efizientzia energetikoa giltzarri den konponbidetzat hartzen da. Ildo beretik, pobrezia energetikoaren gaietan aintzindari den Brenda Boardmanek, pobrezia eta pobrezia energetikoaren arteko diferentzia, kapital inbertsio beharretan oinarritzen dela defendatzen du (Liddell, 2012), beste behin efizientzia energetikoan fokua jarriz.

Berezitako fenomenoa dela baieztatzen duen korrontearen aurkako argudioekin sartu aurretik, pobrezia nola definitzen den ikustea aproposa liteke eztabaidaren testuingurua zehazte aldera. Hain zuzen, EBren irizpidearen arabera, errentaren medianak adierazitako balioaren \% 60aren azpitik kokatzen diren familiak pobrezia egoeran leudeke ${ }^{10}$, transferentzia

\footnotetext{
9 Ingelesezko excess winter deaths adieraren itzulpena.

${ }^{10}$ Eurostat. Statistics explained. Monetary poverty: http://ec.europa.eu/eurostat/statisticsexplained/index.php?title=Glossary:Monetary_poverty
} 
sozialak kontuan hartu ostean. Hortaz, EBko kide diren estatuak definizio honetan oinarrituta neurtuko lukete pobreziaren fenomenoa euren herrialdeetan. Pobrezia adierazle absolutu eta erlatiboen arteko eztabaida akademikoa lan honen helburuetatik haratago doanez, ukituko ez bada ere, pobrezia neurtzeko indarrean dagoen adierazle honen izaera erlatiboa ikusita (Damián, 2009), bere ezaugarrien inguruan hainbat zertzelada ematea egoki ikusten da analisi honi osotasuna emateko.

Pobreziaren neurketa erlatiboaren aitatzat hartzen den (Damián, 2009) Peter Townsend egileak adierazitakoaren gisa, pobrezia erlatiboki ulertzearen erroan, gizartean bultzatu eta onesten diren, dieta, ekintza, bizi baldintzak eta erosotasunak erdiesteko beharrezko baliabideak izatea legoke (Townsend, 1979). Hau da, hitz gutxitan, esan liteke gizartean indarrean dagoen bizitza estiloan parte hartu ahal izateko baliabide nahikoak izatean datzala ikuspuntu honen muina. Pobreziaren neurketarako \% 60eko atalasea egile beraren proposamena izan bazen ere (Abel-Smith eta Townsend, 1965), bere muga eta kontraesanak berehala identifikatu zituela esan daiteke. Hain zuzen, egindako kritika zorrotzenetariko bat, medianaren edozein portzentaiaren hautua guztiz arbitrarioa denaren aipamena da (Townsend, 1979). Kritikekin jarraituz Damián-ek (2009) agerian utzi bezala, familien errenten beherakada orokortua gertatzen denean - krisi ekonomikoetan kasu - pobreziak ere behera egingo luke errentaren medianaren balioaren murrizketagatik. Ondorioz, egilearen hitzak erabiliz «emaitza aldrebesak» (Damián, 2009, 32. Or.) emango lituzke ikuspegi honek horrelako kasuetan. Egile berdinak, neurketarako modu honek populazioaren hainbat segmentu kontaketatik baztertzen dituela argudiatzen du, adibide esanguratsu bat erabiliz. Zehazki, euren errenta \% 60ko atalasea baino altuagoa den, baina, oinarrizko zerbitzuen gabezia duten familien egoera dakar mahai gainera. Askotan, besteak beste, osasuna, garraiobideak edota edateko ura bezalako zerbitzuak faltako lituzkete, euren beharrak ezingo lituzketelarik ase. Dena dela, definizio ofizialaren arabera pobreak ez direnez, gobernuaren laguntza programetatik baztertuak geratuko lirateke.

Azken honetatik zintzilik geratu den hariari helduz, Gerbery eta Filčák (2014) egileek adierazi bezala, pobreziak ez luke soilik errenta baxuekin lotura, fenomeno are konplexuagoa liteke. Hau da, multidimentsionala litzateke izatez. Egile berdinen hitzetan, dimentsio aniztasun honen baitan, dimentsio garrantzitsu bat energiarena litzateke, gizarte modernoetan bizi eta parte hartzeko oinarrizkotzat jotzen dutelarik. Damián (2009) egileak esan bezala, Townsend-ek berak pobreziaren izaera multidimentsionalari begi-keinu bat egin ziola argudiatu liteke, bere lanean baliabide adiera erabiltzen baitzuen errenta adiera beharrean. Zehazki, pobrezian eragina luketen ondoko baliabideak identifikatu zituen: Errenta monetarioa (soldatak, pentsioak, irabaziak,etab.), kapital aktiboak (higiezinen balioa, aurrezkia, 
etab.), gauzetan ordaindutako ondasun eta zerbitzuak, zerbitzu publikoak, eta autokontsumoa, opariak eta familiakideek eskainitako laguntza (Townsend, 1979). Pobreziaren ulermen multidimentsionalean sakonduz, Damian-en (2009) arabera, Townsend-en anbizio handienetariko bat pobrezian eragina zuten gabezi forma ezberdinekin, gabezia indize bat sortzea zen, hau taxutzera iritsi ez bazen ere.

Aipatu berri denez, pobreziari ikuspegi multidimentsional batetik helduta, energia dimentsio garrantzitsu bat liteke, hartara, Middlemiss (2017) egileak adierazi bezala, pobrezia energetikoari tratamendu berezia ematean, bien arteko elkarrekiko erlazio eta menpekotasun konplexuak aztertzeari uko egingo litzaioke. Pobrezia energetikoarekin amaitzeko neurriak efizientzia energetikora mugatuz.

Atal honen baitako kaosari nolabaiteko ordena emateko eta sintesi gisa, hurrengo ondorioak atera litezke. Batetik, pobreziaren egungo definizioaren baitan - \% 60ko atalasea-, aproposa izan liteke pobrezia energetikoa era berezian tratatzea. Izan ere, Phimister et al. (2015) egileek aipatu bezala, errenta baxuek eragin zuzena duten arren, beste hainbat faktoreren eragina nabaria liteke. Zentzu honetan, Chaton eta Lacroix (2018) egileek identifikatutako hainbat faktore aipa litezke, hala nola, efizientzia energetikoa, etxebizitzaren egoera edota osasun arazoak. Ikuspegi honen baitan, pobrezia energetikoari aurre egiteko hartu beharreko neurriak efizientzia energetikoaren alorrekoak lirateke bereziki. Bestetik, pobreziaren definizio multidimentsionalean oinarrituz gero, baliteke, pobrezia energetikoa eta pobrezia orokorra bereiztea egokia ez izatea. Middlemiss-ek (2017) esandakoari jarraituz, energia, pobreziaren dimentsio gisa identifikatuta, azterketa bateratuak elkarrekintza konplexuak azaleratzen lagunduko luke, horrela efizientzi energetikoaz haratago doazen neurriekin aurre egitea posible egingo litzatekelarik. Hortaz, galdera honek analisia sakon eta zehatzagoa beharko lukeela iritzi den arren, lehen esplorazio honen arabera, gakoa pobreziaren definizioaren baitan legoke.

\section{Pobrezia energetikoaren lekua Ekonomia Sozial eta Solidarioaren baitan}

Ekonomia Sozial eta Solidarioaren -ESS aurrerantzean - definizio bat ematea ez litzateke lan samurra. Bere gerizpean topa daitezken erakundeak heterogeneotasun handia erakusten dute, bai forma juridiko, merkatuarekiko artikulazio eta helburuei dagokionean; ondorioz, gisa honetako nabardurek adostasun zabala duen definizio bat gailentzea eragozten dute (Pérez de Mendiguren et al., 2008). ESSren baitako debate eta ikuspuntu ezberdinak jasotzea lan honen esparrutik haratago doanez, bere muina era 
labur eta zehatzean jasotzen duela iritziz, REAS (2011) erakundeak darabilen definizioari so egingo zaio. Erakunde honen arabera, ESS «jarduera ekonomikoaren ikuspegi bat litzake» "ekonomia bere egiazko helburuaren mende jartzen duena: gizakiaren garapen pertsonalerako, eta gizarte eta ingurumenaren garapenerako behar diren oinarri materialak modu iraunkorrean eskaintzea» (REAS, 2011, 1 Orr.). Kontzeptuaren nondik norakoak definitzen jarraituz, honakoa azpimarratzen du erakundeak: «banakako eta taldekako beharrak asetzeko alternatiba bideragarri eta iraunkorra da, bide batez gizartea eraldatzeko tresna gisa ere finkatu behar dena» (REAS, 2011, 1. Orr.). Definizio honekin beraz, ESSk bere erdigunean pertsonak jartzen dituela argudiatu liteke, ekonomia beren beharren betekizunetara bideratuz ${ }^{11}$.

ESS ren eta pobrezia energetikoaren nolabaiteko bidegurutzea topatzeko ariketan, komenigarria litzateke pobrezia energetikoaren definizio zabalduenetariko bat gogora ekartzea. Hots, sozialki eta materialki beharrezkoa den energia zerbitzu maila erdiesteko familia baten ezintasuna (Belaïd, 2018, Boemi et al., 2017, Bouzarovski, 2014, Bouzarovski et al., 2016, Maxim et al., 2017, Okushima, 2016, Okushima, 2017, Robinson et al. 2017, Scarpellini et al., 2015 Thomson et al., 2017) bezala definitzen duena. Ikuspegi hau kontuan hartuz, bien arteko lehen elkargunea beharren esparru horretan ezartzea posible liteke. Arestian ikusi dugunez, energia zerbitzuak ezinbestekoak suertatzen dira pertsonen oinarrizko beharrak asetzeko, besteak beste, argiztapena, garbiketa, sukaldaketa eta beroketa batzuk aipatzearren (Haas et al., 2008). Hortaz, ESSren papera pobrezia energetikoari dagokionean, behar energetiko hauek asetzeko modu alternatibo eta sostenigarriak proposatu eta sustatzean egon liteke. Honekin lotuta, García eta Mundó (2014) egileek pobrezia energetikoari era espezifikoan aurre egitea justifikatzeko azaltzen dituzten arrazoi berak, ESSk arazo honetan izan ditzaken jardute lerroak markatzeko ere baliogarria izan liteke. Batetik, pobrezia energetikoaren ondorioak ikustarazten eta energia, bizitza duhin baterako oinarrizko eskubide gisa aitortzeko urratsak ematen lagundu lezake. Bestetik, gabezia energetikoko egoerak ekiditeko neurri, estrategia eta ekintzak aurrera eraman litzake.

Behin elkargune orokorra definituta eta ESSk pobrezia energetikoaren baitan izan ditzakeen jardute lerroak ikusita, analisiari nolabaiteko proiekzioa ematearren, azken hauetan jarriko da fokua, alegia, jardute lerroetan. Bi lerroak era berezian tratatuko dira jarraian.

${ }^{11}$ Egun indarrean dagoen ekonomia eredua ere pertsonen beharren menpe legokeela argudiatu liteke, kontsumitzaileen gustu eta beharren arabera antolatzen dela merkatuko eskaintza defendatuz. Dena dela, hainbat egileek adierazi dutenez, besteen artean Galbraith-ek (1958), mekanismoa alderantzizkoa litzateke, kasu askotan, merkatuak pertsonen beharrak sorrarazten dituztelarik marketing eta tankera horretako tresnak erabiliz. 


\subsection{Energia pobreziaren ondorioak ikustarazi eta energia, bizitza dubin baterako oinarrizko eskubide gisa aitortzeko urratsak ematen lagundu}

ESSk oinarri gisa lukeen printzipio esanguratsuenetariko bat, lanaren printzipioa litzateke, bere baitan, lanaren dimentsio kulturalak (REAS, 2011) garrantzizko lekua izango lukeelarik. Lanaren dimentsio kulturala aipatzean, enpleguaren eta lanaren arteko bereizketari egingo litzaioke erreferentzia. Izan ere, ESSren baitan, enpleguak, besteren konturako lan kontratuaren forma juridikoa islatuko luke soilik. Aldiz, lana kotzeptuaren bidez, bere funtzio sozial, politiko, ekonomiko eta gizatiarrak azpimarratuko lituzke, inongo forma juridiko edota administratibori lotuta egon gabe (REAS, 2011). Hortaz, ESSk bere analisian bai merkatuko eta baita merkatuz kanpoko lanak kontuan hartzen dituela argudiatu liteke, modu batean, zainketa eta erreprodukziorako lanei ikusgarritasuna emanez.

Ildo honetatik, Garcia eta Mundó (2014) egileek aipatu bezala, energia ezinbesteko suertatzen da erreprodukziorako lanak aurrera eramateko. Era berean, erreprodukziorako lanak pertsonen garapenerako premiazkoak diren arren —elikadura, higienean, zainketa, etab.—, orokorrean, etxebizitzaren baitan eta ordaindu gabe egiten direnez, sozialki gutxi baloratuak darraite. Esan gabe doa, hein handi batean emakumeek gauzatzen dituztela lan horiek (Garcia eta Mundó, 2014). Aipatu berri dugun egoera honek, Garcia eta Mundó-ren (2014) esanetan, pobrezia energetikoa bigarren lerro batean mantendu izana eragin du, zor zaion garrantzia eman ez zaiolarik.

Horiek horrela, merkatu eta merkatuz kanpoko lanaren dikotomiarekin puskatuz, merkatuz kanpoko lanei zor zaien aintzatespena emateko, pobrezia energetikoaren ondorioak ikustarazteak sendotasuna eman liezaioke auzi honen defentsari. Hortaz, ESSren eta pobrezia energetikoaren artean nolabaiteko sinergiak antzeman litezke zentzu honetan, erreprodukziorako lanak duhintasunez aurrera eramateko gainditu beharreko arazo gisa planteatu litekeelarik.

\subsection{Gabezia energetikoko egoerak ekiditeko neurri, estrategia eta ekintzak aurrera eraman}

Gabezia energetikoko egoerak ekiditeko ESSko erakundeek hartu ditzazketen neurri, estrategia eta ekintzei dagokienean, hiru fronte nagusi identifika litezke zeinetan ESSk garrantzizko papera izan lezakeen. Horiek, ondorengoak lirateke; identifikazioa, energia horniketa, sentsibilizazioa eta erlazionaturiko jarduerak eta interbentzioa. Jarraian horietako bakoitza era berezian aztertuko da. 


\subsubsection{IDENTIFIKAZIOA}

Pobrezia energetikoa identifikatzeko Dubois (2012) egileak darabiltzan estrategien artean, identifikazio deszentralizatua da horietako bat, «identifikazio partehartzailea» (Dubois, 2012, 110. Orr.) terminoa ere erabiltzen duelarik berori erreferentzia egiteko. Estrategia honen muina, pobrezia energetikoaren identifikazioa tokiko aktoreen esku uztea da, horien identifikaziorako kriterioei dagokienean erabateko askatasuna emanez. Egile beraren esanetan, horiek, tokiko errealitatea gertutik ezagutzen dutenez, pobrezia energetikoa hautemateko gaitasun handiagoa izango lukete.

Hori horrela izanik, ESSri begiratuz gero, pobrezia energetikoa pairatzeko arriskuan dauden kolektibo ezberdinekin lan egiten duten erakundeak ikus litezke. Hauetako askok, pobrezia energetikoaren gaia zuzenean lantzen ez badute ere, balio erantsia eman dezakete onargarria den energia zerbitzu maila bat erdiesteko ezintasuna duten familiak identifikatzeko ahaleginean (Garcia eta Mundó, 2014). Hain zuzen, ESSren baitako erakundeak kolektibo anitzekin lan egiten dutenez —esaterako, adineko pertsonak, haur eta nerabeak, atzerritarrak edota desgaitasun fisiko edo psikikoak dituzten pertsonak-, tokian tokiko errealitatearen ezagutza sakonagoa daukate, eta horrenbestez, pobrezia energetikoko egoeran dauden familia edota gizabanakoak identifikatzeko ahalmen handiagoa dute (Garcia eta Mundó, 2014).

\subsubsection{ENERGIA HORNIKETA, SENTSIBILIZAZIOA ETA ERLAZIONATURIKO JARDUERAK}

Azken urte hauetan, energia hornikuntzaren alorrean energia berriztagarrietako kooperatibak -EBK aurrerantzean - hedapen esanguratsua bizi izan dutela esan liteke. Kanada, AEB, Erresuma Batua, Danimarka eta Alemanian fenomeno honek dimentsio esanguratsua lortu du (Heras-Saizarbitoria et al., 2018), eta eskala txikiago batean bada ere, gurera ere ailegatu dela esan liteke. Adibide gisa, estatu espainiarreko energia berriztagarrien hornikuntzarako bi kooperatiba handienek, Som energia eta GoiEner, 22.045 eta 3.590 bazkide zituzten hurrenez hurren 2016 urtean, guztira 3.598 eta 28.206 kontratu kudeatzen zituztelarik (Jaio Gabiola et al., 2016). Gisa honetako ekimenak, ESSren baitan kokatuko lirateke, egituraketa kooperatiboa izateaz gain, horietako askok izaera eraldatzaile nabarmena baitute. Horren adibide dira aurrez aipatu ditugun bi kooperatiba horiek, beren misioan \% 100 berriztagarria den energia modelo batera jotzeko desira (Jaio Gabiola et al., 2016).

Iturri berriztagarrietako energiaren kontsumoari bultzada emateaz gain, modelo energetikoan transformazio sakonak eragiteko potentziala duten 
agente gisa kontsideratu litezke EBKk. Izan ere, Heras-Saizarbitoria et al. (2018) egileek adierazi bezala, herrialde industrializatu gehientsuenetako energia sektoreak estatu edota korporazioen menpe egon dira, ekoizpen eta hornikuntzak kontzentrazio maila handia erakutsi duelarik. Egile berdinen esanetan, EBKk, tokian tokiko eta komunitate mailan txertatutako ekimenak dira, eta hortaz, energia sistema deszentralizatu baterako lehen zutarriak ezarriko lituzketela argudiatu liteke.

Egungo eredu energetikoaren eta pobrezia energetikoaren arteko loturetan sakonduz, Chester (2014) egileak, kausalitate indartsua dagoela argudiatzen du bien artean, pobrezia energetikoaren gorakadaren errua energia sektorearen liberalizazioari egotziz. Testuinguru honetan, beraz, EBKk marrazten duten etorkizuneko modelo energetiko deszentralizatuak, pobrezia energetikoaren gaiarekin tentuz jokatu beharko lukeela iritzi da. Honen harira, Walker (2008) egileak, energia sistema deszentralizatuen eta pobrezia energetikoaren arteko loturak aztertuz, elkargune positibo eta negatiboak identifikatzen ditu. Negatiboekin hasiz, batetik, energia ekoizteko beharrezko kapital ondasunen kostu altuak azpimarratzen ditu. Horrekin batera, komunitate mailako instalakuntza hauek duten konplexutasun maila eta know how beharra oztopo gisa ikusten ditu. Azkenik, gizartearen zenbait segmentutan, zehazki, alokairuan bizi direnentzat, sistema hau aplikagarritasun zailekotzat hartzen du, jabeek inbertsio hauek egiteko ezkortasuna izango dutela aurreikusten du eta. Alderdi positiboetara igaroz, lehenik, energia zirkuitu laburragoek eragingo lituzketen aurrezkiak ditu mintzagai, hots, energia merkeago lortuko litzatekeela argudiatzen du. Bestetik, fidagarritasun handiagoko sistema litzatekeela defendatzen du, sare nagusiaren mozketen aurrean, energia erreserba batekin kontatzea posible izango delako.

Etorkizuneko modelo energetiko hipotetikoak albo batera utziz eta egungo testuingurura bueltatuz, aipagarria da, Europako Batzordeak 2009an indarrean jarritako direktiba bat ${ }^{12}$, zeinaren bitartez, EBko estatuak pobrezia energetiko arriskuan dauden familia eta gizabanakoei energia hornikuntza bermatzera behartuak dauden (Jaio Gabiola et al., 2016). Gida-lerro juridiko honen pean, Espainian bono social delakoa jarri zen martxan 2009 urtean bertan, aurrez definituriko hainbat ezaugarri betetzen dituzten gizabanakoei, faktura elektrikoan \% 25eko deskontua aplikatzen diena (Jaio Gabiola et al., 2016). Bono social delakoaren azterketa, lan honen esparrutik haratago doan arren, analisiaren norabidea zehazteko bere ezaugarri adierazgarri baten berri ematea komenigarria ikusten da. Zehazki, erreferentziazko komertzializatzaile (Comercializadoras de referencia) bezala

12 2009ko Uztailaren 15eko 2009/72/CE direktiba. 
katalogatutako energia hornitzaileak daude soilik legez bono social delakoa ematera behartuak (Jaio Gabiola et al., 2016). Horrenbestez, EBKk ez leudeke hizpide dugun deskontua aplikatzeko legalki derrigortuak egongo. Are gehiago, Jaio Gabiola et al. (2016) egileek adierazten dutenez, ez dago Espainian bono social delakoa eskaintzen duen EBKrik.

Jaio Gabiola et al. (2016) egileek hiru arrazoi nagusi identifikatzen dituzte bazkide zaurgarrienei tarifa murriztua ez eskaintzeko. Lehena, EBKen ibilbide laburragatik, —2010 urteaz geroztik sortuak izan baitira denakbaliteke oraindik auzi hau ez planteatu izana da. Bigarren arrazoia, oraindik, irabazi ekonomikoen maila, neurri horien aplikagarritasuna ziurtatzeko haina ez izatea da; eta hirugarrena eta azkena, gisa honetako tarifa baten eskaintza EBKn lehentasunetako bat ez izatea da. Behin errealitate honen atzean egon litezkeen arrazoi posible batzuk ikusita, pentsa liteke, energia hornikuntzari dagokionean ESSko erakundeen jarduna pobrezia energetikoaren murrizketarekin bateragarria ez dela, edota are gehiago, fenomenoaren anplifikazioa eragingo lukeela. Honen aurrean, esan liteke, ESSren ezaugarri den Irabazi Asmorik Gabekoa izatearen printzipioak (REAS, 2011) egoera irauli lezakeela, EBKen eta pobrezia energetikoaren artean sinergiak sortuz.

Ezer baino lehen, Irabazi Asmorik Gabeko printzipioaren nondik norakoak aipatzea komenigarri ikusten da. REAS (2011) erakundearen arabera «sortzen dugun aberastasuna banatzea da. Emaitzek gizartearen zerbitzura egon behar dute eta ez kapital pribatuaren metaketaren zerbitzura» (REAS, 2011, 10. Orr.), hau da, irabaziak sozializatzea dela printzipio honen muina argudiatu liteke. Eraunde berberak, «lor litezkeen irabaziak ekimen ekonomikoaren iraunkortasuna hobetzeko, proiektu sozialak bultzatzeko, ekimen solidario berrietarako edo garapenerako lankidetza-programetarako inbertitzea» (REAS, 2011, 10. Orr.) proposatzen ditu irabazien sozializazio bide bezala. Hartara, Irabazi Asmorik Gabeko izateak, EBKei pobrezia energetikoa murrizteko neurriak hartzeko tartea emango lieke, modu honetan bien artean lotura sendoa ezarriz.

\subsubsection{INTERBENTZIOA}

Aurrez aipatu dugunez, ESSko erakundeak gizarteko kolektibo anitzekin egiten dute lan, horietako asko pobrezia energetikoa pairatzeko zaurgarritasun egoeran daudelarik (Garcia eta Mundó, 2014). Horrenbestez, aurrez aipatzen genuen identifikazio lanetik haratago, ESSko erakundeak kolektibo horiek osatzen dituzten familia eta gizabanakoekin harreman zuzena dutenez, pobrezia energetikoari aurre egiten lagundu diezaiekete interbentzio zuzenaren bitartez. Interbentzio hauek forma oso ezberdinak hartu ditzakete, Garcia eta Mundó (2014) egileek, jarraian zerrendetuko 
diren kolektiboekin interbentzio potentzial handia aurreikusiko lukete: Adineko pertsonak, haur eta nerabeak, etorkinak eta desgaitasun edota gaixotasun kronikoak dituzten pertsonak.

\section{Ondorioak}

Lan honetan zehar ikusi denez, pobrezia energetikoaren gaiak interpretazio eta ikuspuntu ugari ditu aztergai den fenomenoaren alderdia edozein delarik ere. Ezaugarri hau dela medio, literaturan, adostasun eza eta gehiegizko barreiaketa gailentzen dira, fenomenoaren ulermenerako edozein hurbilketa saio nabarmenki zailduz. Testuinguru honetan, lan honen egilearen partetik, adostasuna sortuko duen hurbilketa teoriko baten beharra hautematen da. Horretarako, marko bateratu horrek aurkeztu litzazkeen ezaugarrietako batzuk identifikatuko dira jarraian.

Kontzeptualizazioaren aldetik, energia zerbitzuen ikuspuntutik marko bateratu horretarako lehen oinarriak jarri direla ikusi da. Ikuspegi dikotomikoaren aurka joan beharrean, ikuspegiaren erdigunean kokatzen diren onarpenak beste marko baten barruan sartzen dituela esan daiteke. Hau da, energia zerbitzuen ikuspuntuak ez du ukatzen Herrialde Garatu eta Garapen Bidekoen artean pobrezia energetikoak oso bestelako ezaugarriak aurkezten dituenik. Aldiz, pobrezia energetikoak aurkeztu ditzazkeen forma ezberdinak onartuz, marko analitiko berdinaren pean aztertzen ditu. Are gehiago, garapen ekonomiko mailak ez ezik, beste hainbat faktorek pobrezia energetikoaren baitan eragin dezakeen heterogeneotasuna jasotzeko aukera emango luke hurbilketa honek. Aztertu denez, energia zerbitzuen ikuspegiaren baitan, oinarrizko tresna, zaurgarritasun faktoreak lirateke. Beraz, Bouzarovski eta Petrova (2015) egileek proposatu bezala, edozein eremu geografikotan pobrezia energetikoa aztertzeko baliogarriak izango diren zaurgarritasun faktoreak barneratu beharko lirateke. Horiek horrela, etorkizunean, ahalik eta osatuena izango den zaurgarritasun faktoreen zerrenda bat osatzeko beharra ikusten da. Honek, marko teoriko bateratu bat eraikitzeko ahaleginari bultzada handia emango liokeela iritzi da.

Etorkizunari begira eta lan honetako ondorioetatik eratorrita, pobrezia energetikoaren inguruan gauzatu litezkeen bi lan lerro aipa litezke; Pobrezia Energetikoa ikuspegi sozio-ekonomiko integratzaile batetik sakonean aztertzea eta bere neurketarako proposamen zehatzak egitea, hurrenez hurren. Lehenengo lan lerroari helduz, literatura akademiko eta grisa oinarri hartuta, fenomenoaren kontzeptualizazio ariketa bat garatzeko aukera aurkezten da gaiaren inguruko alderdi esanguratsuenak jasoz; hala nola, definizioa, tipologia, nazioarteko egoera, EAEn eta Estatuan izandako harrera, neurketa eta adierazleak. Aipatu gisa, orain arte argitaratutako lanek, ikus- 
puntu desberdinetatik aztertu dute Pobrezia Energetikoaren gaia, eta ondorioz, heterogeneotasuna, gehiegizko barreiaketa eta adostasun eza gailendu dira. Horrenbestez, gaiaren inguruan aritzen diren artikulu akademiko eta literatura grisaren bilduma esanguratsua den arren, oraindik ez da azaldu Pobrezia Energetikoa ulertzeko modu ezberdinak era ordenatu eta sistematikoan biltzen dituen lanik. Gauzak horrela, etorkizunean jorratzeko lan lerro behinenetako bat, Pobrezia Energetikoaren ikuspuntu edo pentsamendu korronte ezberdinen printzipio eta postulatuak era ordenatu eta sistematikoan azaltzea da, korronte bakoitzaren baitan orain arte burututako ikerkuntza saiakeren berri emanez.

Behin Pobrezia Energetikoa aztertzeko proposatu diren ikuspegi teoriko ezberdinak jasota, bigarren lan lerroa fenomenoaren ulermena EAEko testuingurura egokitzeko kontzeptualizazio ariketa batekin erlazionatuko litzake. Horretan, Pobrezia Energetikoan eragina izan dezaketen EAEko ezaugarri sozial, teknologiko eta ekonomikoak tentuz kontsideratuko lirateke, kasurako eskuragarri dauden datu empirikoak oinarri hartuta gaia sakonean aztertuz. Behin EAE-rako marko kontzeptuala gorpuztu delarik, Pobrezia Energetikoaren identifikazio eta neurketarako adierazle baten garapenerako oinarri sendoak finkatuta egongo litateke. Beraz, lan lerro honetatik erator litekeen beste ahalegin interesgarri bat aplikazio praktikoa izango duten tresnak garatzea izango da, hots, Pobrezia Energetikoa identifikatzeko eta neurtzeko adierazle bat proposatzea. Ondoren, EAE mailan, Pobrezia Energetikoaren inzidentzia eta ezaugarri bereiztaileak neurtzeko erabilgarria izan daitekeena. Esanguratsua da, ahalegin hau ez litzatekeela hutsetik hasi beharko, izan ere, Eguia Careaga Fundazioaren SiiS-Dokumentazio eta Ikerketa Zentruak, Gipuzkoako Foru Aldundiaren enkarguz, Pobrezia Energetikoaren Txostenak gauzatu baititu 2012, 2014 eta 2018 urteetarako. Horrenbestez, nolabaiteko oinarri estatistikoa erabilgarri egongo litzateke.

Estimazio horietarako erabiliko litekeen oinarri estatistiko bera hartuz, beste analisi interesgarri baterako atea zabaltzen da. Esate baterako, EAEko testuinguruan, Pobrezia Energetikoa zein punturaino izan daitekeen pobrezia orokorretik berezitutako fenomenoa aztertzeko aukera azaltzen da. Ahalegin horrek, ezinbestean, pobreziaren inguruko gogoeta teorikoa eskatzen badu ere, ikerketaren helburu zehatzetatik haratago doanez, pobreziaren inguruko literatura esanguratsuak markatutako printzipioetara mugatuko da argudiaketa.

Mintzagai izan ditugun etorkizuneko bi lan lerro potentzial hauek erabakitzaile publikoentzako izan dezakeen garrantzia ikusirik, beren inplikazioa lortzeak berebiziko garrantzia izango luke. 


\section{Eskerrak}

Egileak eskerrak eman nahi dizkio EHUko Ińaki Heras irakasleari artikuluari buruz egindako iradokizunengatik. Artikulu hau Eusko Jaurlaritzak finantzaturiko GIC 15/176 ikerketa-taldearen emaitza bat da.

\section{Bibliografia}

Abel-Smith, B., \& Townsend, P. (1965). The poor and the poorest. G. Bell \& Sons Limited.

Albaladejo, Á. F., \& Berenguer, C. M. (2016). Los movimientos sociales en las agendas mediática y política en España: el caso de la PAH. OBETS: Revista de Ciencias Sociales, 11(1), 165-185.

Aristondo, O., \& Onaindia, E. (2018). Counting energy poverty in Spain between 2004 and 2015. Energy Policy, 113, 420-429.

Assembly, U. G. (1948). Universal declaration of human rights. UN General Assembly.

Atsalis, A., Mirasgedis, S., Tourkolias, C., \& Diakoulaki, D. (2016). Fuel poverty in Greece: Quantitative analysis and implications for policy. Energy and Buildings, 131, 87-98.

Belaï, F. (2018). Exposure and risk to fuel poverty in France: Examining the extent of the fuel precariousness and its salient determinants. Energy Policy, 114, 189-200.

Boemi, S. N., Avdimiotis, S., \& Papadopoulos, A. M. (2017). Domestic energy deprivation in Greece: A field study. Energy and Buildings, 144, 167-174.

Bouzarovski, S., \& Petrova, S. (2015). A global perspective on domestic energy deprivation: Overcoming the energy poverty-fuel poverty binary. Energy Research \& Social Science, 10, 31-40.

Bouzarovski, S. (2014). Energy poverty in the European Union: landscapes of vulnerability. Wiley Interdisciplinary Reviews: Energy and Environment, 3(3), 276-289.

Bouzarovski, S., Tirado Herrero, S., Petrova, S., \& Ürge-Vorsatz, D. (2016). Unpacking the spaces and politics of energy poverty: Path-dependencies, deprivation and fuel switching in post-communist Hungary. Local Environment, 21(9), 1151-1170.

Bueno Mendieta, Gorka. (2007). Energia urriko mundu baterako gida. Manu Robles-Arangiz institutua, Bilbao.

Buzar, S. (2007). When homes become prisons: the relational spaces of postsocialist energy poverty. Environment and Planning A, 39(8), 1908-1925.

Chaton, C., \& Lacroix, E. (2018). Does France have a fuel poverty trap?. Energy Policy, 113, 258-268.

Chester, L., \& Morris, A. (2011). A new form of energy poverty is the hallmark of liberalised electricity sectors. Australian Journal of Social Issues, 46(4), 435-459. 
Chester, L. (2014). Energy Impoverishment: Addressing Capitalism's New Driver of Inequality. Journal of Economic Issues, 48(2), 395-404.

Damián, A. (2009). A dónde nos ha llevado el enfoque relativo de la pobreza de Peter Townsend (Fundamentos y Debate).

Day, R., Walker, G., \& Simcock, N. (2016). Conceptualising energy use and energy poverty using a capabilities framework. Energy Policy, 93, 255-264.

Dubois, U., \& Meier, H. (2016). Energy affordability and energy inequality in Europe: Implications for policymaking. Energy Research \& Social Science, $18,21-35$.

Dubois, U. (2012). From targeting to implementation: The role of identification of fuel poor households. Energy Policy, 49, 107-115.

Galbraith, John Kenneth. "The affluent society.» New York, New American Library (1958).

García, M., \& Mundó, J. (2014). La energía como derecho. Cómo afrontar la pobreza energética.

Gerbery, D., \& Filčák, R. (2014). Exploring multi-dimensional nature of poverty in Slovakia: access to energy and concept of energy poverty. Ekonomicky Casopis, 62(6), 579-97.

Gouveia, J. P., Seixas, J., \& Long, G. (2018). Mining households' energy data to disclose fuel poverty: lessons for Southern Europe. Journal of Cleaner Production.

Haas, R., Nakicenovic, N., Ajanovic, A., Faber, T., Kranzl, L., Müller, A., \& Resch, G. (2008). Towards sustainability of energy systems: A primer on how to apply the concept of energy services to identify necessary trends and policies. Energy Policy, 36(11), 4012-4021.

Healy, J. D., \& Clinch, J. P. (2002). Clinch: Fuel Poverty in Europe: A Cross Country Analysis Using A New Composite Measurement. In Environmental Studies Research Series Working Papers.

Herrero, S. T. (2017). Energy poverty indicators: A critical review of methods. Indoor and Built Environment, 26(7), 1018-1031.

Heras-Saizarbitoria, I., Saéz, L., Allur, E. \& Morandeira, J. (2018): The Emergence of Renewable Energy Cooperatives in Spain: A Review

Hills, John (2011) Fuel poverty: the problem and its measurement. CASE report, 69. Department for Energy and Climate Change, London, UK.

Hills, J. (2012). Getting the measure of fuel poverty: Final Report of the Fuel Poverty Review.

Jaio Gabiola, E., Paredes gázquez, J. D., \& Sánchez Rodriguez, J. A. (2016). El bono social y las cooperativas energéticas verdes: situación y perspectivas. $R E$ VESCO. Revista de Estudios Cooperativos, (122).

Legendre, B., \& Ricci, O. (2015). Measuring fuel poverty in France: Which households are the most fuel vulnerable?. Energy Economics, 49, 620-628.

Lenz, N. V., \& Grgurev, I. (2017). Assessment of energy poverty in new European Union member states: The case of Bulgaria, Croatia and Romania. International Journal of Energy Economics and Policy, 7(2) 
Li, K., Lloyd, B., Liang, X. J., \& Wei, Y. M. (2014). Energy poor or fuel poor: What are the differences?. Energy Policy, 68, 476-481.

Liddell, C. (2012). The missed exam: Conversations with Brenda Boardman. Energy Policy, 49, 12-18.

Maxim, A., Mihai, C., Apostoaie, C. M., \& Maxim, A. (2017). Energy poverty in Southern and Eastern Europe: Peculiar regional issues. European Journal of Sustainable Development, 6(1), 247.

Maxim, A., Mihai, C., Apostoaie, C. M., Popescu, C., Istrate, C., \& Bostan, I. (2016). Implications and measurement of energy poverty across the European Union. Sustainability, 8(5), 483.

Middlemiss, L. (2017). A critical analysis of the new politics of fuel poverty in England. Critical Social Policy, 37(3), 425-443.

Miniaci, R., Scarpa, C., \& Valbonesi, P. (2014). Energy affordability and the benefits system in Italy. Energy Policy, 75, 289-300.

Modi, V., McDade, S., Lallement, D., \& Saghir, J. (2005). Energy services for the Millennium Development Goals. Energy services for the Millennium Development Goals.

Nussbaum, M. C. (2001). Women and human development: The capabilities approach (Vol. 3). Cambridge University Press.

Okushima, S. (2017). Gauging energy poverty: A multidimensional approach. Energy, 137, 1159-1166.

Okushima, Shinichiro. «Measuring energy poverty in Japan, 2004-2013.» Energy Policy 98 (2016): 557-564.

O'Meara, G. (2016). A Review of the Literature on Fuel Poverty with a Focus on Ireland. Social Indicators Research, 128(1), 285-303.

Papada, L., \& Kaliampakos, D. (2017). Energy poverty in Greek mountainous areas: a comparative study. Journal of Mountain Science, 14(6), 12291240.

Papada, L., \& Kaliampakos, D. (2016). Measuring energy poverty in Greece. Energy Policy, 94, 157-165.

Pérez de Mendiguren, Juan Carlos, Enekoitz Etxezarreta Etxarri, and Luis Guridi Aldanondo. "¿De qué hablamos cuando hablamos de Economía Social y Solidaria? Concepto y nociones afines.» Comunicación presentada a las XI Jornadas de Economía Critica (2008): 27-29.

Petrova, S., Gentile, M., Mäkinen, I. H., \& Bouzarovski, S. (2013). Perceptions of thermal comfort and housing quality: exploring the microgeographies of energy poverty in Stakhanov, Ukraine. Environment and Planning A, 45(5), 1240-1257.

Phimister, E. C., Vera-Toscano, E., \& Roberts, D. J. (2015). The dynamics of energy poverty: evidence from Spain. Economics of Energy \& Environmental Policy.

REAS-Red de redes de economía alternativa y solidaria (2011). Carta de la Economía Solidaria. 
Robinson, C., Bouzarovski, S., \& Lindley, S. (2017). 'Getting the measure of fuel poverty': The geography of fuel poverty indicators in England. Energy Research \& Social Science.

Roberts, D., Vera-Toscano, E., \& Phimister, E. (2015). Fuel poverty in the UK: Is there a difference between rural and urban areas?. Energy policy, 87, 216223.

Sánchez, C. S. G., Mavrogianni, A., \& González, F. J. N. (2017). On the minimal thermal habitability conditions in low income dwellings in Spain for a new definition of fuel poverty. Building and Environment, 114, 344-356.

Scarpellini, S., Rivera-Torres, P., Suárez-Perales, I., \& Aranda-Usón, A. (2015). Analysis of energy poverty intensity from the perspective of the regional administration: Empirical evidence from households in southern Europe. Energy policy, 86, 729-738.

Schumacher, K., Cludius, J., Forster, H., Greiner, B., Hunecke, K., Henkmann, T., \& Van Nuffel, L. (2015). How to end Energy Poverty? Scrutiny of Current EU and Member States Instruments. European Parliament's Committee on Industry, Research and Energy.

Thomson, H., Bouzarovski, S., \& Snell, C. (2017). Rethinking the measurement of energy poverty in Europe: A critical analysis of indicators and data. Indoor and Built.

Thomson, H., \& Snell, C. (2013). Quantifying the prevalence of fuel poverty across the European Union. Energy Policy, 52, 563-572.

Townsend, P. (1979). Poverty in the United Kingdom: a survey of household resources and standards of living. University of California Press. 